Adelaida Andoni ${ }^{1 *}$, Eda Delilaj ${ }^{1}$, Fatos Ylli ${ }^{2}$, Krenaida Taraj ${ }^{1}$, Arjan Korpa ${ }^{1}$, Kledi Xhaxhiu', Armand Çomo ${ }^{1}$

${ }^{1}$ University of Tirana, Faculty of Natural Sciences, Department of Chemistry, Blv. "Zog I", Tirana, Albania

${ }^{2}$ University of Tirana, Institute of Applies Nuclear Physics, Tirana, Albania
Short Communication ISSN 0351-9465, E-ISSN 2466-2585 UDC:543.51:662.613.11.13 doi:10.5937/zasmat1804539A

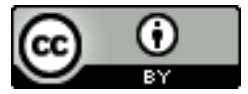

Zastita Materijala 59 (4) 539 - 542 (2018)

\title{
FTIR spectroscopic investigation of alkali-activated fly ash: Atest study
}

\begin{abstract}
Fly ash is byproduct of thermal power plants. Millions tons of fly ash is produced globally. Fly ash is disposed partly in landfills but it could also be released into the atmosphere in the past. Fly ash is composed of silica, alumina, iron oxide, magnesia and activated carbon. Due to large surface area, fly ash is very suitable for catalysis application. It is well known and well reported that fly ash can be converted into efficient adsorptive material such as zeolites. In the present work, the transformation of fly ash into zeolite was carried out by alkali activation process of aluminosilicates material. The alkali solution releases silicon and aluminum ion into solution, which form afterwards Si-OH and Al-OH groups. FTIR spectroscopy was applied to characterize fly ash chemical activation, in order to conduct a study making intensive use of infrared spectroscopy and further to provide information on chemical bond vibrations in the molecular units of fly ash. The FTIR spectrum of solid base fly ash (SBFA) after chemical activation shows a significant increase in peak intensity of the band for-OH group.
\end{abstract}

Keywords: fly ash, chemical activation, catalyst, FTIR spectroscopy.

\section{INTRODUCTION}

Fly ash is also known as pulverized fuel ash, is a coal combustion product that is composed of fine particles [1,2]. Treatment of fly ash with alkali solution produces a "zeolite precursor" and it is characterized by a three-dimensional structure and long- and mid-range disorder [1-7]. The product obtained after alkali activation is a material that possesses high surface area and can be used in catalysis, especially in fine chemical, petrochemical and pharmaceutical industries [1,2]. Fly ash consists of silica, alumina, iron oxide, magnesia and in minor amount comprises activated carbon as well $[1,5]$. Additionally, it is well reported that fly ash has been used as a catalyst, for $\mathrm{H}_{2}$ production, deSOx, deNOx, hydrocarbon oxidation etc. $[1,6]$. Furthermore, it is well reported $[1,2,6]$, that fly ash can be chemically activated by $\mathrm{NaOH}$ solution giving though the surface basicity and making it

\footnotetext{
${ }^{*}$ Corresponding author: Adelaida Andoni

E-mail: adelaida.andoni@fshn.edu.al

Paper received: 06.10.2018.

Paper accepted: 05.11.2018.

Paper is available on the website: www.idk.org.rs/journal
}

catalytically active. In the current work fly ash was also chemically activated by an alkali activation process of alumino-silicates material in close resemblance to the studies reported in the literature [1-7]. The aim is to successfully activate fly ash and to acquire a deeper understanding by means of FTIR spectroscopy regarding information on chemical bond vibrations in the molecular units of activated fly ash. FTIR spectroscopy was applied to characterize fly ash before and after chemical activation. IR spectra clearly indicated an augment in the peak intensity of the band for $-\mathrm{OH}$ group after chemical activation for the fly ash. Fourier transform infrared (FTIR) spectroscopy technique is rapid and requires minimal or no sample preparation [2,5, 8-12]. FTIR provides a global fingerprint of samples [2,5,8-12].

\section{EXPERIMENTAL}

Sample preparation: The solid fly ash used was F-type, rich in silica and alumina content [13]. The activation process was carried out, by rigorously following the procedure reported by Jain et al. [1]. The solid base fly ash (SBFA) was synthesized by chemical activation of fly ash with $\mathrm{NaOH}(98 \%$, Merck) at different concentrations of 
alkali solutions incrementally increasing up to 50 wt.\% $[1,2,5]$. The chemical activation was carried out in a round flask (equipped with a stirring bar and a condenser) by taking the mixtures of fly ash and $\mathrm{NaOH}$ solution, followed by subsequent heating at $110^{\circ} \mathrm{C}$ under stirring and aging for 2 days preserving the temperature. After ageing, in order to remove leached compounds and excess of $\mathrm{NaOH}$ the obtained pulp was washed with distilled water $[1,2,5]$. The chemically activated fly ash was dried at $110^{\circ} \mathrm{C}$ for $24 \mathrm{~h}$ and thermally stabilized by calcination at $450^{\circ} \mathrm{C}$ for $4 \mathrm{~h}$ in static conditions $[1,2,5]$.

Vibrational spectroscopic measurements: FTIR spectra were collected by Nicolet 6700 spectrometer, manufactured by Thermo Electron, which allows spectral measurements in NIR (12000 - $\left.4000 \mathrm{~cm}^{-1}\right)$ and MIR (4000 - $400 \mathrm{~cm}^{-1}$ ) region. This system works in two geometries, the geometry of the transmission and reflectance (Attenuated Total Reflection-ATR). In this study, the transmission geometry is used in the range mid Infra-Red $\left(4000-400 \mathrm{~cm}^{-1}\right)$ with a resolution of 4 $\mathrm{cm}^{-1}$. The spectra were analyzed using OMNIC program. Samples were analyzed prior to drying at $120^{\circ} \mathrm{C}$ for 3 hours.

\section{RESULTS AND DISCUSSION}

The FTIR spectrum of fly ash (FA), before and after chemical activation is shown in Figure 1 (inserted spectra). Fly ash was chemically activated with the highest concentration of alkali solution (50 wt.\%) $[1,2,5]$. The FTIR spectra of solid base fly ash (SBFA) shows a broad band in the region between $3400-3000 \mathrm{~cm}^{-1}$, which is attributed to surface $-\mathrm{OH}$ groups of $-\mathrm{Si}-\mathrm{OH}$ in excellent agreement with reported IR spectra in the literature $[1,2,5]$. The broadness of the band is due to the strong hydrogen bonding as well reported in the literature $[1,2,5,12]$. Jain et al. [1] reported that the hydroxyl groups are not isolated and hence a high degree of association is experienced as a result of extensive hydrogen bonding with other hydroxyl groups.

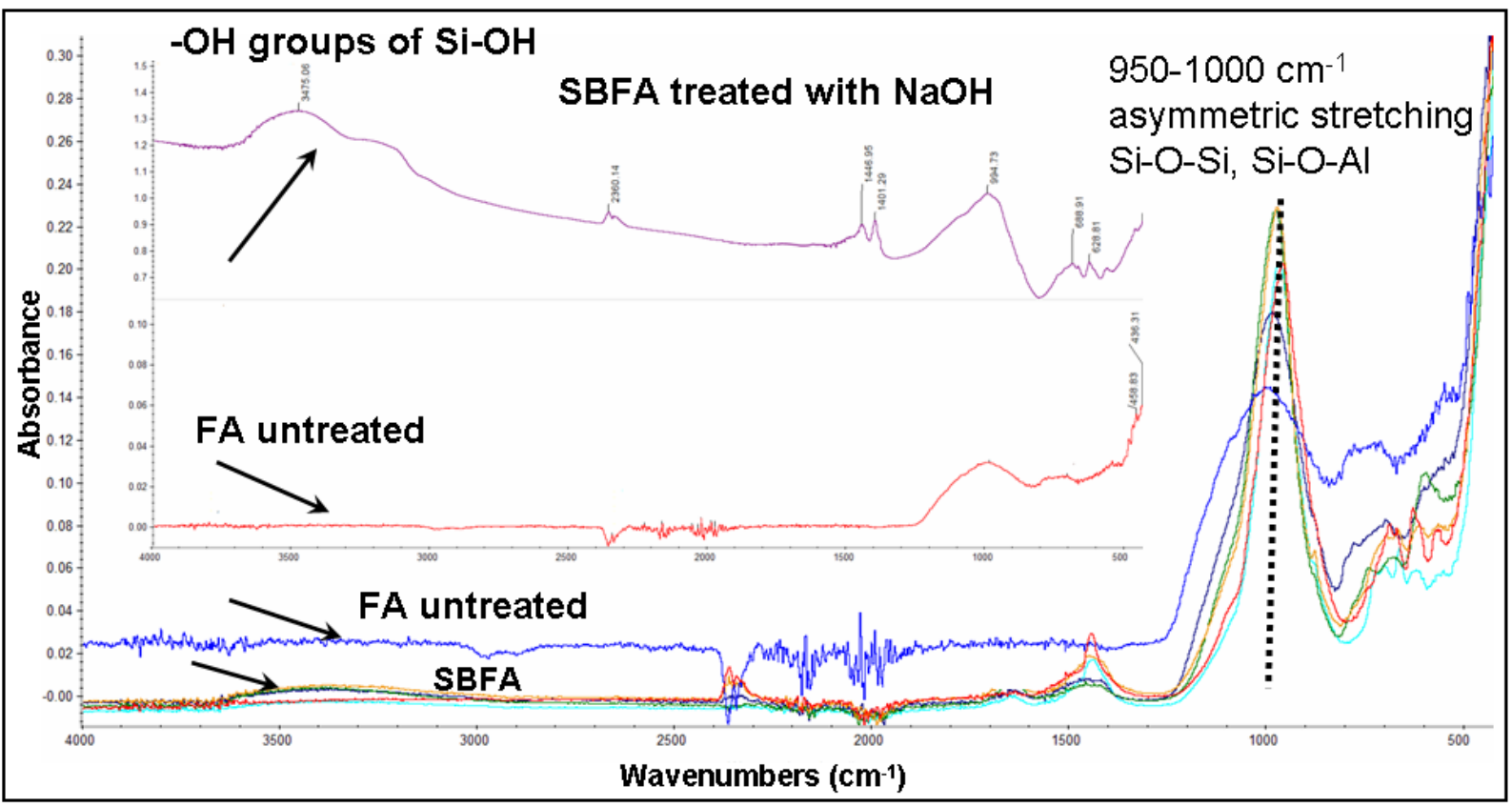

Figure 1. Wide scan FTIR spectrum fly ash (FA, untreated) and a series of wide scans FTIR spectra of solid base fly ash (SBFA, treated) treated with different concentration of alkali solution. The highest concentration was $50 \mathrm{wt}$. \% of $\mathrm{NaOH}$. The inserted spectra indicate FA before and after treatment with $\mathrm{NaOH}$ (with the highest concentration of $\mathrm{NaOH}, 50$ wt.\%).

Slika 1. Širok FTIR spektar serije pepela (FA, neobrađen) i serija FTIR spektara pepela od čvrstog baznog pepela (SBFA, tretiranog) tretiranog različitom koncentracijom alkalnog rastvora. Najviša koncentracija je bila 50 tež. \% NaOH. Umetnuti spektri pokazuju FA pre i posle tretmana sa $\mathrm{NaOH}$ (sa najvećom koncentracijom $\mathrm{NaOH}, 50$ tež. \%).

It is relevant to mention that water which absorbs on the surface gives also a broad band in the region between $3400-3000 \mathrm{~cm}^{-1}$, however, FTIR spectrum of untreated FA displays a flat line in the region $3400-3000 \mathrm{~cm}^{-1}$. The latter suggests that the broad band in the FTIR spectrum of SBFA (after chemical activation) in the region 3400-3000 $\mathrm{cm}^{-1}$ belongs to the $-\mathrm{OH}$ groups of $-\mathrm{Si}-\mathrm{OH}$ and not 
to the $-\mathrm{OH}$ of water molecules. Furthermore, water gives a characteristic peak at $1650-1630 \mathrm{~cm}^{-1}$ in the IR spectrum, which is attributed to bending mode $\left(\delta_{\mathrm{O}-\mathrm{H}}\right)$ of water molecule $[1,2,5,12]$. In this respect, both FTIR spectra before after chemical activation of fly ash (Figure 1) show no peaks at 1650-1630 $\mathrm{cm}^{-1}$ region. Nevertheless, minor amount of water absorbed on the surface of FA or SBFA cannot be excluded.

Figure 1 gives also a series of wide scans of FTIR spectra activated with $\mathrm{NaOH}$ at different concentrations. There is an increase in the peak intensity of the band for the $-\mathrm{OH}$ groups upon increasing the concentration of $\mathrm{NaOH}$ incrementally. This is, however, more evident in the peaks intensities appearing in the range 1000-950 $\mathrm{cm}^{-1}$, which are attributed to the $\mathrm{Si}-\mathrm{O}-\mathrm{Si}$ and $\mathrm{Si}-\mathrm{O}$ Al asymmetric stretching $[1,2,5,12]$. The most intensive peak for the $\mathrm{Si}-\mathrm{O}-\mathrm{Si}$ and $\mathrm{Si}-\mathrm{O}-\mathrm{Al}$ asymmetric stretching belongs to the sample treated with highest concentration of $\mathrm{NaOH}$, i.e. 50 wt.\% $[1,2,5,12]$. It is also reported that that internal vibrations in silicates appear as wide bands at 1062, 1064 and $1092 \mathrm{~cm}^{-1}$ [7]. The latter is in good agreement with the current work.

Figure 2, displays yet again a series of FTIR spectra for SBFA samples with incrementally increased $\mathrm{NaOH}$ concentrations in a narrow range $1400-400 \mathrm{~cm}^{-1}$, including the FTIR spectrum of the untreated FA as well. It is evident from Figure 2 that upon increasing the concentration of alkali solution, the peak position for the Si-O-Si and Si-OAl asymmetric stretching has moved slightly to lower wavenumbers. The latter may be explained due to the increased population of $-\mathrm{OH}$ groups on the surface. This shift in the range of $1100-950 \mathrm{~cm}$ 1 was also reported by Fernandez-Jimenez and Palomo [7]. Additionally, the Si-O-Si bending vibrations appear in the range $\sim 450-430 \mathrm{~cm}^{-1}$, $[1,2,5,12]$.

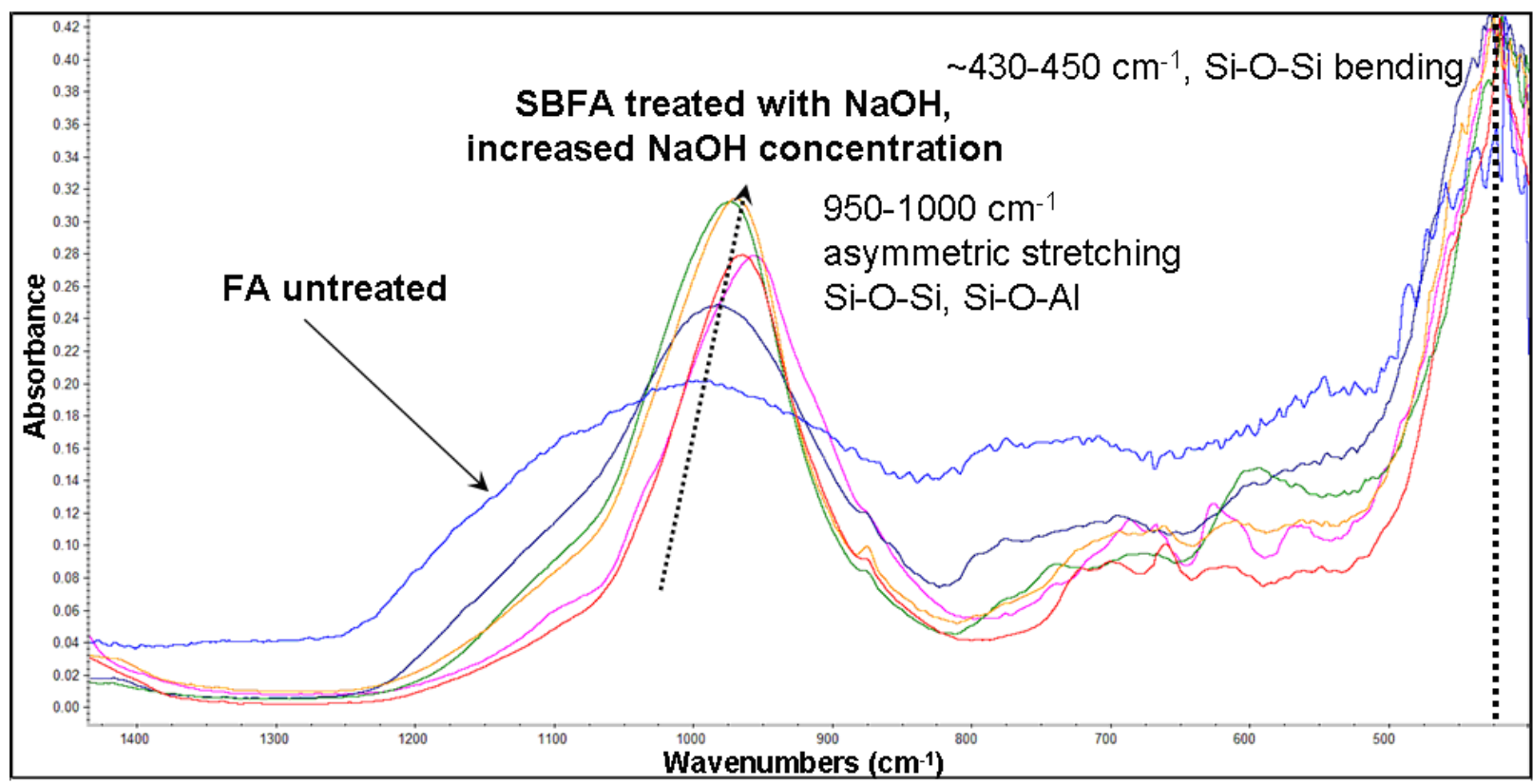

Figure 2. FTIR spectrum of fly ash (FA, untreated) and a series of FTIR spectra of solid base fly ash (SBFA, treated) treated with different concentration of alkali solution in the region $1400-400 \mathrm{~cm}^{-1}$.

Slika 2. FTIR spektar elektrofilterskog pepela (FA, neobrađen) i serija FTIR spektara pepela od pune baze (SBFA, tretirana) tretirana sa različitim koncentracijama alkalnog rastvora u rasponu 1400-400 cm-1.

To this end, the spectra of Figure 1 shows signals of SBFA at $1440-1400 \mathrm{~cm}^{-1}$ which are also observed in the IR spectra of SBFA reported in the literature $[1,2,5,12]$.

\section{CONCLUSION}

In the present work fly ash was activated by alkali solution and further characterized by FTIR spectroscopy. FTIR spectra featured similarities to a large extend with those reported in the literature.
Additionally, FTIR spectroscopy technique proved to be very effective for interpreting and understanding information on chemical bond vibrations in the molecular units of activated fly ash.

\section{REFERENCES}

[1] D.Jain, C.Khatri, A.Rani (2011) Synthesis and characterization of novel solid base catalyst from fly ash., Fuel, 90, 2083-2088. 
[2] A. Andoni, E. Delilaj, F. Ylli, A. Osmëni, K. Taraj, K. Xhaxhiu (2015) Synthesis of a solid base catalyst from fly ash and its characterization by FTIR spectroscopy. 3-rd International Conference, Harmonization of Environmental Research and Teaching with Sustainable Policy, HERTSPO2015, Shkodra, Albania, 6-8 November 2015. Book of Abstracts and Proceedings, HER_P001, p. 249-253.

[3] A.Corma, S.Bee, A. Hamid, S.lborra, A.Velty (2005) Lewis and Brönsted basic active sites on solid catalysts and their role in the synthesis of monoglycerides., Journal of Catalysis, 234, 340 347.

[4] S.Abello, D.Vijaya-Shankar, J.Perez-Ramırez (2008) Stability, reutilization, and scalability of activated hydrotalcites in aldol condensation., Applied Catalysis A: General, 342, 119-125.

[5] A.Andoni, A.Korpa, K.Taraj, F.Ylli, K.Xhaxhiu, A.Çomo (2017) Catalytic testing of a solid base nanomaterial catalyst from fly ash. Journal of Natural and Technical Sciences, Published by the Academy of Sciences of Albania, 43, 85-92.

[6] S.Wang (2008) Application of solid ash based catalysts in heterogeneous catalysis, Environmental Science \& Technology, 42, 7055-7063.

[7] A.Fernandez-Jimenez, A.Palomo (2005) Midinfrared spectroscopic studies of alkali-activated fly ash structure, Microporous and Mesoporous Materials, 86, 207-214.

[8] A.Andoni (2009) A flat model approach to ZieglerNatta olefin polymerization catalysts Eindhoven: Technische Universiteit Eindhoven.

[9] A.Andoni, J.C.Chadwick, J.W.Niemantsverdriet, P.C.Thüne (2009) Investigation of Planar ZieglerNatta Model Catalysts Using Attenuated Total Reflection Infrared Spectroscopy., Catalysis Letters, 130, 278-285.

[10] A.Andoni (2014) High resolution electron energy loss spectroscopy for studying planar model catalyst: A test of $\mathrm{NO}$ on $\mathrm{Rh}(100)$, Revue Roumaine de Chimie, 59(3-4), 245-249.

[11] K.Taraj, I. Malollari, F.Ylli, R.Maliqati, A.Andoni, J. Llupa (2018) Spectroscopic study on chemical composition of essential oil and crude extract from Albanian Pinus halepensis Mill., Journal of Agriculture Informatics, 9(1), 41-46.

[12] B.Smith (1999) Infrared spectra interpretation, A systematic approach, CRC Press LLC.

[13] [S.Gjyli, A. Korpa, C.Belviso, T.Tabanelli, F.Cavani (2018) Ndikimi i paramentrave të sintezës në përfitimin e zeoliteve prej hirit fluturues silicor, Bulletin of Natural Sciences, Faculty of Natural Sciences, University of Tirana, 25, 213-220.

\title{
IZVOD
}

\section{FTIR SPEKTROSKOPSKO ISTRAŽIVANJE ALKALNO AKTIVIRANOG PEPELA}

Leteći pepeo je nusproizvod termoelektrana. Milioni tona letećeg pepela se proizvodi širom sveta. Leteći pepeo se delimično uklanja u deponije, ali bi se mogao puštati u atmosferu. Leteći pepeo čine silicijum, glinice, gvožđe oksid, magnezijum i aktivni ugalj. Zahvaljujući velikoj površini, leteći pepeo je veoma pogodan za primenu kao katalizator. Poznato je i prijavljeno je da se leteći pepeo može pretvoriti $u$ efikasan adsorpcioni materijal, kao što su zeoliti. $U$ sadašnjem radu, transformacija letećeg pepela u zeolit izvršena je procesom alkalne aktivacije materijala aluminijum-silikata. Alkalni rastvor daje silicijum i aluminijum jon u rastvoru, koji formiraju posle Si$\mathrm{OH}$ i Al-OH grupe. FTIR spektroskopija primenjena je za karakterizaciju hemijske aktivacije letećeg pepela, kako bi se sprovela studija koja intenzivno koristi infracrvenu spektroskopiju i dalje pruža informacije o vibracijama hemijskih veza u molekularnim jedinicama pepela. FTIR spektar elektrofilterskog pepela (SBFA) nakon hemijske aktivacije pokazuje značajno povećanje intenziteta vršnog opsega za -OH grupu.

Ključne reči: leteći pepeo, hemijska aktivacija, katalizator, FTIR spektroskopija.

\author{
Short Communication \\ Rad primljen: 06. 10. 2018. \\ Rad prihvaćen: 05. 11. 2018. \\ Rad je dostupan na sajtu: www.idk.org.rs/casopis
}

\footnotetext{
(c) 2018 Authors. Published by Engineering Society for Corrosion. This article is an open access article distributed under the terms and conditions of the Creative Commons Attribution 4.0 International license (https://creativecommons.org/licenses/by/4.0/)
} 